\title{
A synthetic study to characterize alluvial groundwater responses to overbank flood recharge
}

\author{
$\underline{\text { S.A. Womera }}{ }^{\text {a }}$, J.F. Costelloe a, T.J. Peterson ${ }^{\text {a }}$ and A.W. Western ${ }^{\text {a }}$ \\ ${ }^{a}$ Department of Infrastructure Engineering, The University of Melbourne, Victoria, Australia \\ E-mail: swomera@student.unimelb.edu.au
}

\begin{abstract}
Groundwater recharge in alluvial river floodplains is a complex process driven by variation in river water levels, overbank flooding, rainfall over the floodplain and subsequent evapotranspiration. In many floodplains, floods are strongly correlated with local rainfall which makes it difficult to quantify groundwater recharge resulting from floods only. This paper investigates the groundwater response characteristics to overbank flooding and rainfall in different synthetic river-aquifer settings. Sets of coupled MIKE SHE/MIKE11 models are developed using 54 years (1960-2013) of river data (water level and discharge) and climatic data (rainfall and evapotranspiration) from the Loddon River, Australia, containing at least 20 overbank floods along a $5 \mathrm{~km}$ wide river floodplain.
\end{abstract}

Results from four different sets of models are compared to compute overbank flood recharge. They are: 1) models with time series of rain and river level data (M1 model), 2) models with time series of river level data but no rain (M2 model), 3) models with time series of rain and river level data (modified for within bank floods only) (M3 model) and, 4) models with data of rain and base flow in the river (M4 model). While the relationship between different overbank flood recharge processes is nonlinear to some degree, in estimating the overbank recharge contribution, we assume linearity. Three different forms of floodplain recharge are lateral recharge from the channel, vertical recharge from the inundated floodplain and rainfall recharge. The results show that the greatest groundwater recharge occurs in strongly connected river-aquifer zones and is controlled by lateral flow from river stage rather than vertical infiltration from rainfall or overbank flow. Omitting rainfall from the model (in the presence of evapotranspiration) results in lower overall water table conditions. Without rain, the model is also not effective in capturing the spatial variations of overbank flood recharge.

In the synthetic river-aquifer systems considered, the key parameters influencing overbank flood recharge are aquifer saturated hydraulic conductivity, floodplain slope, and floodplain permeability. Larger groundwater fluctuations occur in more conductive aquifers as they can transmit groundwater faster and are capable of accepting rapid recharge during flood events, but because of greater transmissivity value, fluctuations quickly dissipate, hence the amount of total recharge by flood sources (lateral + vertical) is lower. Floodplain slope is important in this work as it controls the inundated area of overbank flood events, with high recharge occurring up to the distance to which the floodplain is inundated. A flat model (with slope $=0$ ) is found as the most effective river-aquifer setting for allowing the greatest amount of recharge in any form (both lateral recharge and vertical recharge). Floodplain soil clogging also plays an important role for overbank flood recharge by controlling the infiltration rate through the clogged layer. A more conductive floodplain allows the flooded water to infiltrate quickly throughout the clogging layer, leading to greater amounts of recharge, even from short duration floods. The duration of inundation from large floods is important in determining the amount of recharge in heavily clogged floodplain.

The findings from this research work are currently being used to develop time series models to separate flood recharge from rainfall recharge in alluvial valley settings.

Keywords: Groundwater recharge, overbank floods, rainfall, evapotranspiration, river-aquifer interactions 


\section{INTRODUCTION}

The interaction of groundwater and surface water on floodplains is a complex, yet poorly understood, process driven by river stage, rainfall, overbank flooding, evapotranspiration and the aquifer hydrogeology. Understanding these processes informs groundwater and ecological management within floodplains and may contribute to flood forecasting. In regulated rivers, storages typically reduce overbank flooding and this can put riparian vegetation under water stress which can be compounded by salinization of floodplain soils by saline alluvial groundwater (e.g. Holland et al. (2013)). While to date, there has been considerable research into river-aquifer interactions, groundwater response to overbank floods remains a challenging open question. This paper presents insights from synthetic modelling about the groundwater response during flooding and the response from floodplain inundation, rainfall recharge and lateral flow.

During large overbank floods, extensive flooded areas can provide direct vertical infiltration and percolation to the unconfined aquifer, depending on the soil and aquifer antecedent conditions and aquifer hydraulic conductivities. In addition, the lateral recharge resulting from high river stages during floods can also make an important contribution to the unconfined aquifer (Vekerdy et al. (1998)). Vertical recharge from inundated floodplains has been computed in Doble et al. (2012) by developing an analytical model based on synthetic datasets. However, important climatic inputs, like floodplain rainfall and evapotranspiration, are neglected in this model and also the spatial variability of flood recharge has not been analyzed. The lateral recharge from rising river stages of overbank floods has been modelled analytically using field data by Jolly et al. (1994) and Workman et al. (1999) but did not differentiate between rainfall recharge and inundation recharge. Analytical approaches for modelling groundwater recharge resulting from waterbody inundation during transient channel flow have been developed in the field of irrigation engineering (Goswami (2007)) but the number of analytical approaches is limited because of the variable water depth across the floodplain and varying flood extent. Overbank flood recharge has been numerically modelled (e.g. Wolsky et al. (2006); Khan et al. (2007)) but these studies have been site and event specific and did not go into detail regarding different recharge mechanisms.

Rainfall is also an important potential source for floodplain groundwater and usually the river flood follows intense rainfall over the floodplain or vice versa. Because of a strong correlation between rainfall and river floods, it is difficult to separate the rainfall recharge from the flood recharge (both vertical and lateral). To our knowledge, no previous synthetic studies have quantified the spatial extents of different forms of recharge during overbank floods. Finding appropriate methods to separate lateral recharge, vertical inundation recharge and rainfall recharge during large floods is challenging. Use of multiple isotopes (e.g. King et al (2015)) may be useful to distinguish different recharge mechanisms, though this requires collection of expensive field data. Simple analytical approaches, such as time series models, are also capable of decomposing groundwater hydrographs based on contributions from different sources (Peterson and Western (2014)). Recent works by Shapoori et al (2015a, 2015b) have applied time series models for separating the effects of pumping and climate in groundwater hydrographs but this approach has not yet been applied to separating overbank flood recharge processes from rainfall recharge. A key challenge for the time series approach is the validation of the component separation. This paper conducts a synthetic study to characterize alluvial groundwater responses to overbank floods and rainfall. Coupled MIKE SHE/MIKE 11 models are developed with river, rainfall and evapotranspiration data as input. Results from different sets of models are compared to quantify the controls from different sources on overall groundwater recharge during flood events. We define overbank flood recharge as the total recharge occurring from rising river stage and overbank inundation. The understanding and results obtained from the present work will be used for future development of time series models for separating overbank flood recharge from rainfall recharge.

\section{METHODOLOGY}

MIKE SHE (Refsgaard and Storm, 1995) is a fully integrated surface water-groundwater modelling tool that includes major hydrological processes like evapotranspiration, rainfall, overland flow, unsaturated flow, groundwater flow, and channel flow and their interactions. MIKE SHE uses the river modelling tool MIKE 11 for interacting with the river, either as river-saturated zone exchange flow or overbank flow over the floodplains. MIKE SHE/MIKE 11 simultaneously solves the Saint Venant equation for surface water flow and the Richards' equation governing unsaturated/saturated subsurface flow with a physical coupling between the two domains which provides insight into the groundwater responses to large floods. 


\subsection{Model development}

Figure 1 shows the conceptual model of the synthetic riveraquifer system. The model is symmetrical having the river at the center. The trapezoidal river section is $25 \mathrm{~m}$ wide at top, $22.5 \mathrm{~m}$ wide at bottom and $1000 \mathrm{~m}$ long. Synthetic river dimensions (width, depth, bank slopes, etc.) approximately match the Loddon River dimensions (Loddon River Environmental Flows Scientific Panel, 2002). The aquifer is $5000 \mathrm{~m}$ wide (including the river), homogeneous and isotropic; $30 \mathrm{~m}$ thick with an impermeable base and has no flow boundaries on the left and right. Time series rainfall and evapotranspiration are given as inputs in the upper

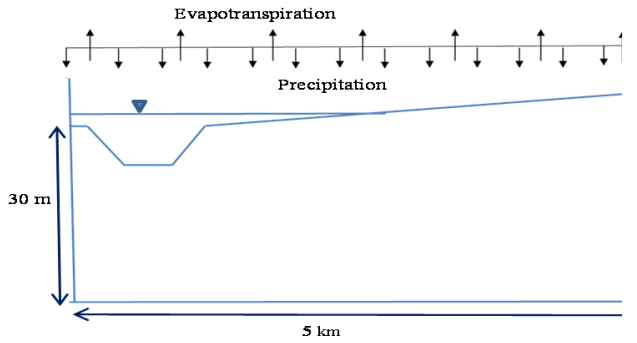

Figure 1. Conceptual model of river-aquifer system. boundary of the model domain. 54 years' time series river data are simulated in the MIKE 11 model. Spatial discretization is applied $25 \mathrm{~m}$ horizontally and $0.1 \mathrm{~m}$ vertically in the model domain. The top $1 \mathrm{~m}$ of the aquifer is defined as the clogging layer (i.e. floodplain soil) of the floodplain. The soil parameters for the unsaturated zone soil model are obtained from Rawls et al. (1982) and Van Genuchten (1980). The models are initially run for 20 years to obtain the initial water level profiles for latter simulations. The time steps were 24 hours for 54 years run and 3 hours for the simulation of flood events.

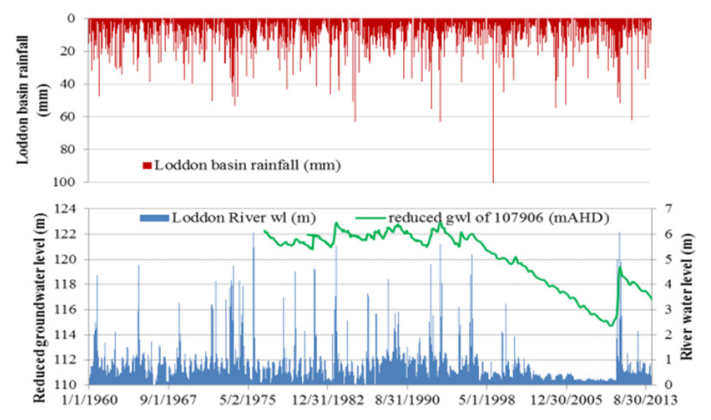

Figure 2. Upper-Mid Loddon River basin data.

In order to provide realistic climate and river level data to the synthetic model, data for MIKE 11 river inputs are daily river stage and discharge from Loddon River station 407203, and MIKE SHE climate inputs are daily rainfall and daily potential evapotranspiration (averaged from monthly data) from station 088048 (Figure 2). Over the 54 years of model simulation period from 1960-2013, average discharge in Loddon River is 6 cumecs, average water level is $26.55 \mathrm{~m}$ AHD and average annual rainfall is $524 \mathrm{~mm}$. Observations from the Loddon River basin show that, unsurprisingly, stage and rainfall are correlated and groundwater levels show high recharge after large floods (e.g. 2010-11 floods). Usage of 54 years of data from Loddon River basin into the synthetic river-aquifer system gives at least 20 overbank floods during the model simulation period. These different floods are of different severity and different pre-flood climate and aquifer conditions. Table 1 summarizes the largest floods that occurred in Loddon River during the modelled period. The correlation coefficients (r) between river water levels and rainfall are shown for the flood weeks only.

Table 1: Largest floods in Loddon River (1960-2013)

\begin{tabular}{|c|c|c|c|c|c|c|c|}
\hline Floods & $\begin{array}{c}\text { ARI (years) } \\
(1893-2013)\end{array}$ & $\begin{array}{c}\text { Maximum } \\
\text { discharge } \\
\text { (cumecs) }\end{array}$ & $\begin{array}{c}\text { Maximum } \\
\text { rise of river } \\
\text { stage } \\
(\mathrm{m})\end{array}$ & $\begin{array}{c}\text { Weekly rain } \\
(\mathrm{mm})\end{array}$ & $\begin{array}{c}\text { Monthly rain } \\
(\mathrm{mm})\end{array}$ & $\begin{array}{c}\mathrm{r} \text { (river stage, } \\
\text { rainfall) at } \\
\text { flood week }\end{array}$ & $\begin{array}{c}\text { Intervals } \\
\text { to previous } \\
\text { flood }\end{array}$ \\
\hline 1975 & 40 & 841 & 5 & 26.1 & 151.3 & 0.49 & 1.5 years \\
\hline 1983 & 15 & 598 & 4.7 & 13.6 & 97.4 & 0.13 & 2 years \\
\hline 1993 & 12 & 550 & 4 & 11.8 & 119.2 & 0.77 & 18 days \\
\hline 2010 & 20 & 661 & 5.8 & 48.2 & 70.8 & 0.72 & 84 days \\
\hline
\end{tabular}

Groundwater table variations in an unconfined aquifer provide information about recharge events (Healey and Cook (2002)). Groundwater level rise in any model is computed as the difference between post-flood and pre-flood groundwater levels. Vertical infiltration during overbank floods comes from both inundated floodplain and basin rainfall. Similarly, lateral recharge occurs by rising river stages and also from the flooded areas. While the relationship between different overbank flood recharge processes is nonlinear to some degree, in estimating the overbank recharge contribution, we assume linearity. To separate different forms of overbank flood recharges we have developed an approach for which rise of groundwater levels from four different sets of models are required:

- Total input models (M1): Time series data of rain and river level,

- Without rainfall model (M2): Time series of river data but no rain, 
- Within-bank river model (M3): Time series of rain and river data (no floodplain inundation),

- Base river model (M4): Time series of rain and constant river data (no inundation and base flow only).

Table 2 shows how the rise of groundwater levels from different models is used to identify three different forms of floodplain recharge; i.e. lateral recharge, vertical inundated recharge and rainfall recharge. The

Table 2: Computation of different recharge

\begin{tabular}{|l|l|}
\hline Different forms of recharge & Computation methods \\
\hline Vertical (inundated) recharge & M1 gwl rise - M3 gwl rise \\
\hline Lateral recharge & M3 gwl rise - M4 gwl rise \\
\hline Rainfall recharge & M4 gwl rise \\
\hline flood recharge & M2 gwl rise \\
\hline
\end{tabular}

difference of the groundwater level rising limb (from pre-flood groundwater levels) between M3 and M4 models gives the lateral recharge from rising river stages during flood events. Similarly, the difference between M1 and M3 models give the vertical recharge from flooded areas. M2 models does not have any rainfall component, hence rise of groundwater levels from this model is showing total

Table 3: List of scenarios modelled

\begin{tabular}{|l|l|}
\hline Sensitivity parameter & $\begin{array}{l}\text { Variations in different } \\
\text { models }\end{array}$ \\
\hline $\begin{array}{l}\text { Aquifer saturated hydraulic } \\
\text { conductivity, } \mathrm{K}_{\text {sat }}\end{array}$ & $\begin{array}{l}\text { Gravel, sand, loamy sand, } \\
\text { loam, clay }\end{array}$ \\
\hline $\begin{array}{l}\text { Ratio of floodplain conductivity to } \\
\text { aquifer conductivity, } \mathrm{K}_{\text {floodplain }} / \mathrm{K}_{\text {aquifer }}\end{array}$ & $1,0.1,0.01,0.001,0.0001$ \\
\hline $\begin{array}{l}\text { Floodplain slope, i (positive when } \\
\text { river at lower elevation) }\end{array}$ & $-0.003,-0.001,0,0.001,0.003$ \\
\hline Overbank flood Properties & $\begin{array}{l}\text { Variations in flood } \\
\text { properties }\end{array}$ \\
\hline Flood depth (m) & 2 m to $6 \mathrm{~m}$ \\
\hline Flood discharge (cumecs) & 250 cumecs to 861 cumecs \\
\hline Overbank duration (days) & 1 day- 4 days \\
\hline Flood intervals (weeks) & 2 weeks -727 weeks \\
\hline
\end{tabular}

flood recharge. Rainfall recharge can be computed from the groundwater level variations from M4 models (i.e. no floodplain inundation and constant low river levels). This method is simplistic for handling the complex overbank flood recharge processes but provides a first order assessment of the different forms of overbank flood recharge. Table 3 lists the modelled scenarios that include varying the following parameters; saturated hydraulic conductivity variations $\left(\mathrm{K}_{\text {aquifer }}\right)$, floodplain slope (i), clogging over the floodplain ( $\left.\mathrm{K}_{\text {floodplain }}\right)$ and different flood properties.

\section{RESULTS}

The results of the simulation of the large flood of 1975 (ARI $=40$ years) are presented. It is representative of the wider results and was derived from a model with an aquifer hydraulic conductivity, $\mathrm{K}_{\text {aquifer }}=1.75 \mathrm{~m} / \mathrm{d}$, floodplain slope (river at lower elevation) $=0.001$ and $K_{\text {floodplain }} / K_{\text {aquifer }}=1$. During the 1975 flood the extent of inundation from the simulations was up to $2050 \mathrm{~m}$ from the river.

To show groundwater responses to the modelled scenario, groundwater hydrographs at four different distances from the river are shown in Figure 3. Rising stage in the river during the flood causes steep

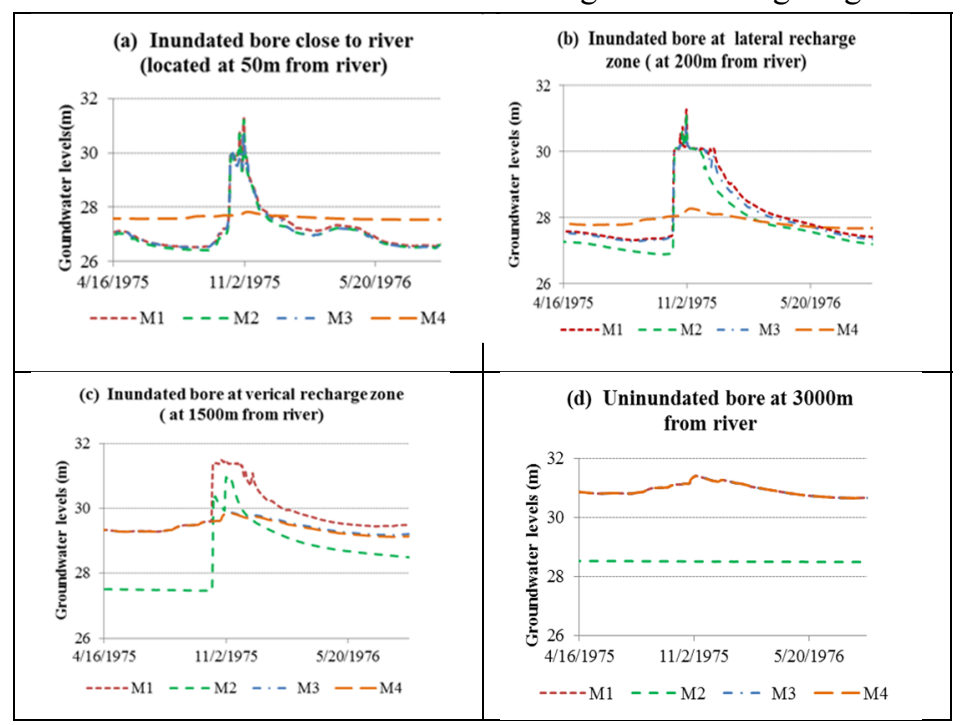

Figure 3. Groundwater hydrographs at different distances from river. hydraulic gradients with the adjacent groundwater levels and results in quick groundwater ridging at the closest locations to the river. As the flood recedes, the river receives discharge from the adjacent higher head aquifer as return flow. M1 and M2 models show similar groundwater rise at $50 \mathrm{~m}$ from the river (Figure 3(a)), indicating that rainfall has little effect in this zone of lateral recharge. However, the M2 (no rain) model shows lower groundwater levels at both $200 \mathrm{~m}$ (Figure 3(b)) and $1500 \mathrm{~m}$ from the river (Figure 3(c)) (both distances were inundated in 1975 flood) and fails to produce any recharge at $3000 \mathrm{~m}$ from river (Figure 3(d)) (not inundated in 1975 flood). The lower

groundwater levels of M2 prior to the flood infers that during low flow conditions, the groundwater storage is not replenished by local rainfall, resulting in lower pre-flood groundwater heads than in the M1 model. The lower overall groundwater storage across the 1975 flood in the M2 model (most accentuated at distances 
$>200 \mathrm{~m}$ from the river) is likely due to the lower initial groundwater heads but also the previously dry soil store may capture more of the vertical flood infiltration from the inundated areas. Exclusion of floodplain inundation from the M3 model reduces groundwater level fluctuations compared to the M1 model at all distances from the river. The differences of groundwater level rises in between M2 and M3 models are significant only at the vertical recharge zone (shown for $1500 \mathrm{~m}$ from river in Figure 3(c)). M4 model fails to show significant amount of groundwater fluctuation from rainfall recharge, compared to flood recharge, except at the furthest distance from the river $(3000 \mathrm{~m})$.

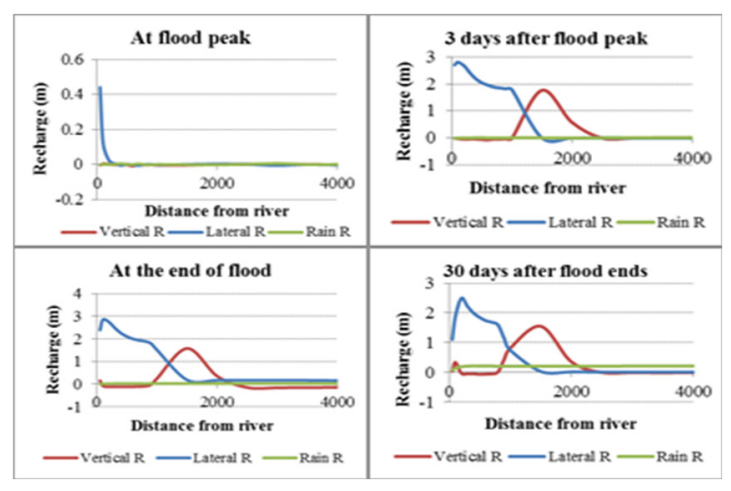

Figure 4. Different forms of recharge during 1975 overbank flood.

Figure 4 shows the three different forms of recharge at different times during and after the flood event. At the flood peak, because of the steep hydraulic gradient between river and adjacent aquifer, only lateral recharge occurs near to the river. After the flood peak, lateral recharge propagates across the floodplain and a mound from vertical inundation recharge also forms. Rainfall recharge is not significant compared to the other two forms of recharge.

Dimensionless plots of the ratio of the groundwater level rise to the flood depth vs. the ratio of the distances from river to the extent of inundation are shown in Figure 5. It shows the extent and magnitude of different forms of recharge. Lateral recharge from increasing river stages influences groundwater levels from near to the river to $80 \%$ of the extent of floodplain inundation and the lateral recharge ranges between $40-60 \%$ of the flood depth within $10-30 \%$ of the inundation extent. Vertical recharge from floodplain inundation becomes measurable at $40-50 \%$ of the inundated distance, ceases close to the end of the inundated distance and reaches a maximum (25-35\% of flood depth) within $70-80 \%$ of the inundated distance. Rainfall recharge at any distance from the river is found not to be significant during the large flood periods. Overall, during large floods like 1975 , the closest $40-60 \%$ of the inundated area from river was dominated by lateral

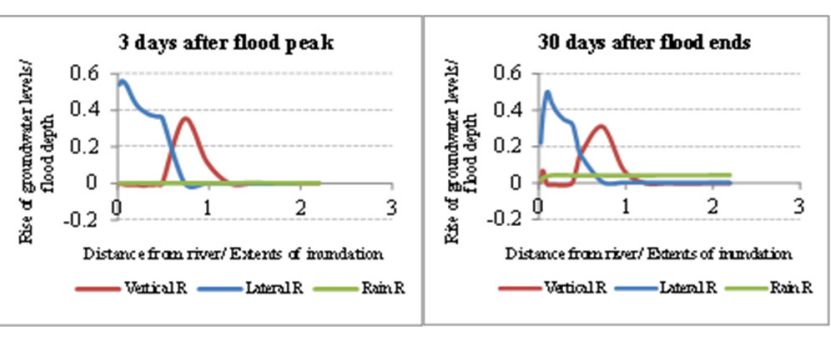

Figure 5. Dimensionless recharges during overbank flood. recharge, whereas vertical recharge was important for the remaining inundated sections. For the floodplain, $40-80 \%$ of the inundated areas experience mixtures of lateral recharge and vertical recharge from overbank floods. Beyond the inundated regions, $10-15 \%$ of the flood extent is influenced by the vertical inundation recharge, probably due to lateral groundwater flow from the mound. The distal dry floodplain sections only receive diffuse rainfall recharge.

To explore the influence of the model parameterization on the identified fluxes, Figure 6 shows the volumetric recharge as a function of the aquifer hydraulic conductivity, $\mathrm{K}_{\text {aquifer }}$, floodplain slope and ratio of the floodplain to aquifer conductivity. Importantly, the recharge volume was the integral of the recharge over the extent and duration of the flood. While one parameter is changing, the other parameters are set as default parameters.

With regard to aquifer conductivity, Figure 6(a) shows that lateral recharge remains the dominant flux. However, when $\mathrm{K}_{\text {aquifer }}>32 \mathrm{~m} / \mathrm{d}$, lateral recharge is no longer the dominant mechanism. This is likely to be due to the high vertical aquifer hydraulic conductivity allowing greater vertical recharge during the period of inundation. This increases the recharge mound and reduces the hydraulic gradient between the river and aquifer, which then reduces the lateral recharge. 


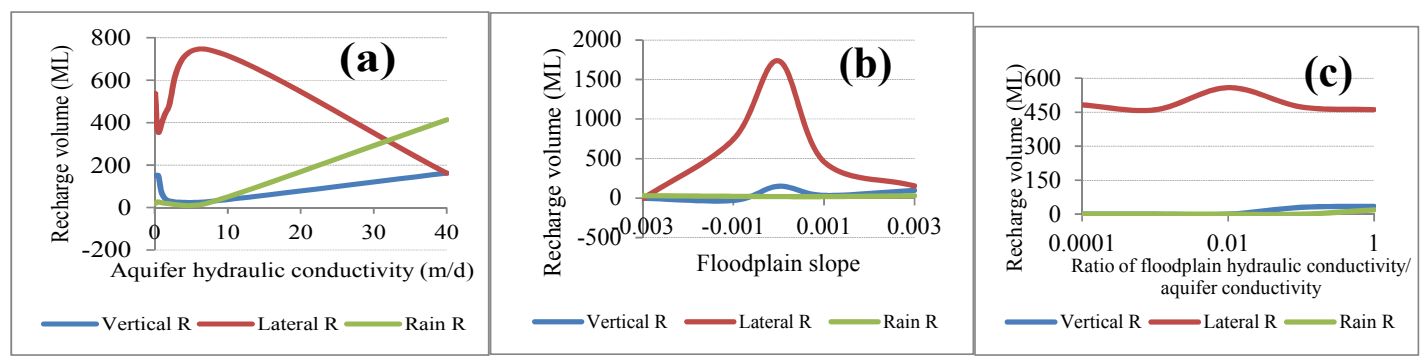

Figure 6. Recharge volume vs. (a) $\mathrm{K}_{\text {aquifer }}$ (b) floodplain slope (c) $\mathrm{K}_{\text {floodplain }} / \mathrm{K}_{\text {aquifer }}$.

With regard to the floodplain slope, Figure 6(b) shows that lateral recharge is the dominant flux for a positive and negative slope. When the slope is positive, lateral recharge remains a dominant mechanism even at a slope of 0.003 . Additionally, vertical recharge is only a notable flux when the slope is modest. The flat model (with slope $=0$ ) is found as the most effective river-aquifer setting for producing the greatest amount of recharge in any form (both lateral recharge and vertical recharge).

Figure 6(c) explores the significance of floodplain clogging by quantifying the fluxes against the ratio of floodplain to aquifer conductivity. It shows that lateral recharge is the dominant flux, explaining most of the total recharge. However, when the ratio is $>0.1$, vertical recharge increases, which most likely explains the corresponding reduction in lateral recharge.

\section{DISCUSSION AND CONCLUSIONS}

To understand overbank flood recharge processes, alluvial groundwater responses are characterized in this synthetic study. Three different forms of floodplain recharge are lateral recharge from the channel, vertical recharge from the inundated floodplain and rainfall recharge. During overbank flood events, lateral recharge is the dominant mechanism when aquifer transmissivity is low to moderate, after which vertical recharge becomes significant. Rainfall recharge is not significant compared to the other two forms of recharge.

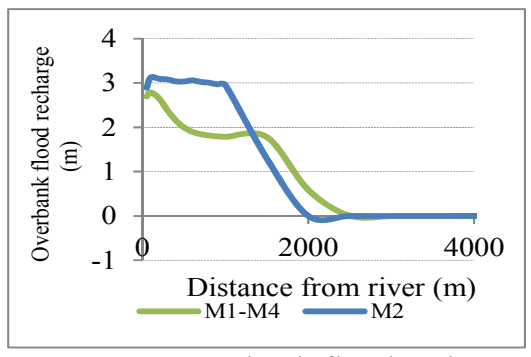

Figure 7. Overbank flood recharge computed by two different ways.
While the relationship between different overbank flood recharge processes is nonlinear to some degree, in estimating the overbank recharge contribution, we assume linearity. To separate different forms of overbank flood recharges, we have developed an approach that compares groundwater level rises from four different sets of models (M1, M2, M3 and M4). To test the assumption of linearity among the complex overbank flood recharge processes, we computed overbank flood recharge in two ways: one is from the difference of groundwater level rises from M1 (rain + flood) and M4 (rain but no flood) models and the other one is from the groundwater level rises in M2 model (flood but no rain). When these two sets of flood recharges are compared in Figure 7 (outputs from model with default parameters), significant difference of recharge amount can be seen in high recharge areas. This infers that the applied method might be too simple for handling the complex overbank flood recharge processes especially in inundated areas that experience mixtures of lateral recharge and vertical recharge from overbank floods and provides only a first order assessment of the different forms of overbank flood recharge.

Figure 8 shows the application of this method to decompose a groundwater hydrograph at $1000 \mathrm{~m}$ from the river (outputs from model with default parameters) based on the contributions from different recharge mechanisms during 1975 flood periods. A key challenge for the time series approach is the validation of the component separation. The findings from this synthetic study will be used for the development and validation of the time series models for separating overbank flood recharge from rainfall recharge.

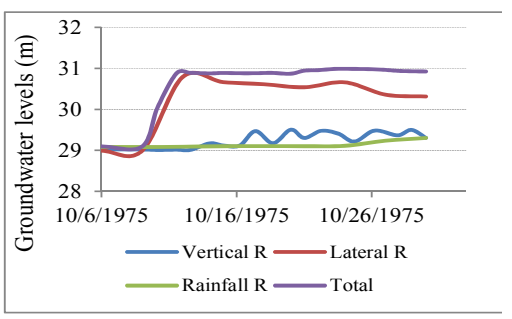

Figure 8. Decomposition of groundwater hydrographs

\section{ACKNOWLEDGMENTS}

Thanks to DHI for providing Labkit student license for this PhD research. We would also like to thank The University of Melbourne for providing the Melbourne International Research Scholarships (MIRS) and The 
Silwati et al., A synthetic study to characterize alluvial groundwater responses to overbank flood recharge

Melbourne International Fee Remission Scholarship (MIFRS) for funding this program. Special thanks to Schlumberger Foundation Faculty for Future Program for providing partial award to support this work.

\section{REFERENCES}

Doble, R.C., Crosbie, R.S., Smerdon, B.D. Peeters, L. and Cook, F.J. (2012). Groundwater recharge from overbank floods. Water Resources Research, 48, (W09522).

Van Genuchten, M.T. (1980). A closed form equation for predicting the hydraulic conductivity of unsaturated soils. Contribution from AR-SEA, USDA, Riverside, CA92501, 892-898.

Goswami, M.D. (2007). Mathematical model on flow regime and water harvesting in inundation plains. Journal of the American Water Resources Association, 43, 588-593.

Jolly, I.D., Walker, G.R. and Narayan, K.A. (1994). Floodwater recharge processes in the Chowilla Anabranch system. Australian Journal of Soil Research, 32, 417-35.

King, A.C., Raiber, M., Cendon, D.I., Cox, M.E., Hollins, S.E. (2015). Identifying flood recharge and interaquifer connectivity using multiple isotopes in subtropical Australia. Hydrology and Earth System Sciences, 19, 2315-2335.

Khan, S., Ahmed, A., Wang, B. (2007). Quantifying rainfall and flooding impacts on groundwater levels in irrigation areas: GIS approach. Journal of Irrigation and Drainage Engineering. 133, 359-367.

Loddon River Environmental Flows Scientific Panel, 2002. Unpublished Report to the North Central Catchment Management Authority and Department of Natural Resources and Environment. Environmental Flow Determination of the Loddon River Catchment: Final Report.

Peterson, T.J., Western, A.W. (2014). Nonlinear time-series modeling of unconfined groundwater head. Water Resources Research, 50, 8330-8355.

Rawls, W.J., Brakensiek, D.L., Saxton, K.E. (1982). Estimation of soil water properties. Transactions of the ASAE 25 (5), 1316-1320.

Refsgaard, J.C., Storm, B. (1995). Computer Models of Watershed Hydrology. Water Resources Publications, Englewood, USA, pp. 809-846.

Shapoori, V., Peterson, T.J., Western, A.W., Costelloe, J.F. (2015a). Decomposing groundwater head variations into meteorological and pumping components: a synthetic study. Hydrogeology Journal.

Shapoori, V., Peterson, T.J., Western, A.W., Costelloe, J.F. (2015b). Top-down groundwater hydrograph time-series modeling for climate-pumping decomposition. Hydrogeology Journal, 23, 819-836.

Van Genuchten, M.T. (1980). A closed form equation for predicting the hydraulic conductivity of unsaturated soils. Contribution from AR-SEA, USDA, Riverside, CA92501, 892-898.

Wolsky, P., Sevenije, H. H. G. (2006). Dynamics of floodplain-island groundwater flow in the Okavango Delta, Botswana. Journal of Hydrology 320, 283-301.

Workman, S.R. and Serrano, S.E. (1999). Recharge to alluvial valley aquifers from overbank flow and excess infiltration. Journal of the American Water Resources Association, 35 (2), 425-432.

Holland, K.L., Turnadge, C.J., Nicol, J.M., Gehrig, S.L. and Strawbridge, A.D. (2013). Floodplain response and recovery: comparison between natural and artificial floods, Goyder Institute for Water Research Technical Report Series No.13/4, Adelaide, South Australia.

Vekerdy, Z. and Meijerink, A.M.J. (1998). Statistical and analytical study of the propagation of floodinduced groundwater rise in an alluvial aquifer. Journal of Hydrology, 205, 112-125. 